\title{
An Alternative Convenient Synthesis of Piperidazine-3-carboxylic Acid Derivatives
}

\author{
Mamoru Kaname, Masae Yamada, Shigeyuki Yoshifuji, and Haruki SashidA* \\ Faculty of Pharmaceutical Sciences, Hokuriku University; Kanagawa-machi, Kanazawa 920-1181, Japan. \\ Received August 22, 2008; accepted October 17, 2008; published online October 20, 2008
}

The short-step synthesis of the unsubstituted, 5-hydroxy- and 5-chloropiperidazine-3-carboxylic acids using an aza Diels-Alder reaction between the 1,3-diene and azodicarboxylate was described. This synthetic methodology could be used for the preparation of the optically active piperazic acid in a $35 \%$ overall yield.

Key words aza Diels-Alder reaction; piperidazine-3-carboxylic acid; azodicarboxylate; piperazic acid

Hexahydropyridazine-3-carboxylic acid (piperazic acid, Piz) is a novel cyclic $\alpha$-hydrazino acid, and a subunit often found in cyclic depsipeptides. Both of its enantiomeric forms have been encountered in many pharmacologically active molecules that include the azinothricin family of antitumor antibiotics, ${ }^{1)}$ verucopeptin, ${ }^{2)}$ the aurantimycins, ${ }^{3)}$ the $\mathrm{C} 5 \mathrm{a}$ antagonist L-156,602, ${ }^{4)}$ the immunosuppressant IC101, ${ }^{5)}$ the oxytocin antagonist L-156,373, ${ }^{6}$ and the matylastantin typeIV collagenase inhibitors. ${ }^{7-9)}$ There are several reports ${ }^{10-13)}$ about the synthesis of the racemic Piz. However, these reports have indicated some obstacles still to be overcome; the aza Diels-Alder (DA) reaction for the construction of the pyridazine framework has a low yield, and the $N$-deprotection was done under strict basic conditions. Recently, Hale and co-workers ${ }^{14,15)}$ described the enantioselective synthesis of the $(3 R)$ - and $(3 S)$-piperazic acids by the electrophilic hydrazination of a chiral oxazorizinone derivative. More recently, Hamada and co-workers reported two synthetic methods for optically active piperazic acids by the use of a proline-catalyzed asymmetric $\alpha$-hydrazination ${ }^{16)}$ and the titanium tetrachloride-mediated aza DA reaction. ${ }^{17)}$ Although $(3 S, 5 S)$-5-HO-Piz was also prepared, the methodology for the preparation of these compounds requires multiple steps, which is not practical. In this report, we describe three new findings for the synthesis of the Piz derivatives; (1) the shortstep convenient synthesis of Piz, (2) the practical preparation of the 5-hydroxy and 5-chloro Piz, and (3) the $(R)$ - and $(S)$ Piz enantioselective synthesis.

\section{Results and Discussion}

Convenient Synthesis of Piperidazine-3-carboxylic Acids In order to prepare the pyridazine-3-carboxylic acid derivative, the DA reaction using the 1,3-diene and azodicarboxylate was carried out. The hetero DA reaction between the di-tert-butyl azodicarboxylate (4) and the 1,3-dienes (1, 2), which have an electron withdrawing group, such as a methoxycarbonyl or cyano group, produced the 1,2-di-tertbutyl 1,2,3,6-tetrahydropyridazine-1,2-carboxylate adducts $(5,6)$ in 47 and $40 \%$ yields, respectively. In contrast, a similar reaction of the azodicarboxylate (4) with methoxy-1,3diene (3), which has an electron donating group, gave the 3methoxypyridazine (7) in almost quantitative yield (Chart 1). ${ }^{18)}$ Therefore, we examined the transformation of the methoxy group in the 3-methoxypyridazine (7) into the cyano group for preparation of the subtitled compounds. We have described the smooth conversion of the methoxy group of the DA adducts into the dimethylphosphono group by treatment with trimethylphosphite in the presence of a Lewis acid. ${ }^{18-20)}$ The treatment of the methoxy DA adduct (7) with trimethylsilyl cyanide (TMSCN) in the presence of $\mathrm{BF}_{3} \cdot \mathrm{OEt}_{2}$ as a Lewis acid at $-40{ }^{\circ} \mathrm{C}$ in dry $\mathrm{CH}_{2} \mathrm{Cl}_{2}$ gave the 3-cyano1,2,3,6-tetrahydropyridazine (6) in $94 \%$ yield via the acyliminium cation intermediate. When $\mathrm{TiCl}_{4}$ was used in this cyanation reaction, the 3-cyanopyridazine (6) was also produced in almost a similar yield. In addition, the one-pot preparation of the 3-cyanopyridazine (6) was established. The reaction of 1-methoxy-1,3-butadiene (3) with di-tert-butyl azodicarboxylate (4) in dry $\mathrm{CH}_{2} \mathrm{Cl}_{2}$ at room temperature, followed by the addition of TMSCN and $\mathrm{BF}_{3} \cdot \mathrm{OEt}_{2}$ at $-40{ }^{\circ} \mathrm{C}$ directly afforded the desired 3-cyanopyridazine (6) in 91\% yield. The DA reaction using 1-trimethylsilyloxy-1,3-diene (8) and azodicarboxylate (4) under similar conditions produced the 6 in $80 \%$ yield (Chart 2 ).

The catalytic hydrogenation of the olefin moiety in $\mathbf{6}$ using $\mathrm{Pd}-\mathrm{C}$ or $\mathrm{PtO}_{2}$ in EtOH was examined. The results of the hydrogenation are summarized in Chart 3 and Table 1. The $10 \% \mathrm{Pd}-\mathrm{C}$ hydrogenation of 6 at the 1 or 3 atom of $\mathrm{H}_{2}$ gave the desired 3-cyanohexahydropyridazine (9) and the aminomethyl derivative (11), which was isolated as the $N$-Boc derivative 12 by the treatment with $\mathrm{Boc}_{2} \mathrm{O}$ (entries $1-3$ ). In the case of using $\mathrm{PtO}_{2}$, 3-cyano-1,2,5,6-tetrahydropyridazine (10) was produced as the major product (entry 5). Fortunately, the $\mathrm{PtO}_{2}$ hydrogenation of $\mathbf{6}$ at the 1 atom of $\mathrm{H}_{2}$ in EtOH with 2 drops of a $70 \% \mathrm{HClO}_{4}$ solution as an additive

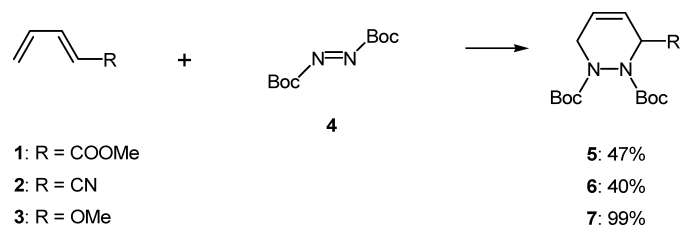

Chart 1

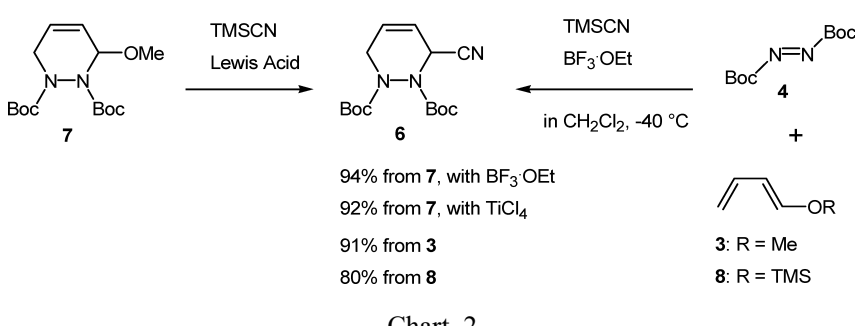

Chart 2 

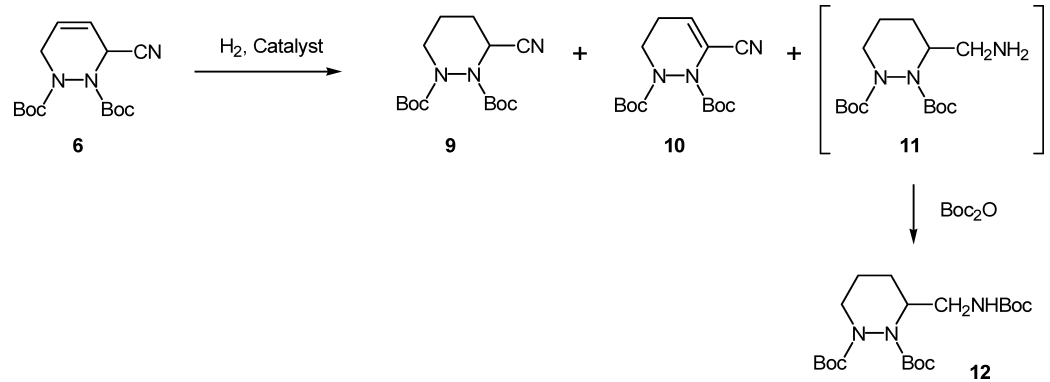

Chart 3

Table 1. Catalytic Hydrogenation of 6

\begin{tabular}{|c|c|c|c|c|c|c|c|}
\hline \multirow{2}{*}{ Entry } & \multicolumn{4}{|c|}{ Reaction conditions } & \multicolumn{3}{|c|}{ Product yield (\%) } \\
\hline & Catalyst & Additive & $\begin{array}{c}\text { Pressure } \\
\text { (atm) }\end{array}$ & $\begin{array}{l}\text { Time } \\
\text { (h) }\end{array}$ & 9 & 10 & 12 \\
\hline 1 & $10 \% \mathrm{Pd}-\mathrm{C}^{a)}$ & - & 3 & 2 & 54 & - & 27 \\
\hline 2 & $10 \% \mathrm{Pd}-\mathrm{C}^{a)}$ & - & 1 & 10 & 64 & - & 22 \\
\hline 3 & $10 \% \mathrm{Pd}-\mathrm{C}^{b)}$ & - & 1 & 3 & 54 & - & 37 \\
\hline 4 & $10 \% \mathrm{Pd}-\mathrm{C}^{b)}$ & $\mathrm{HClO}_{4}$ & 1 & 1 & 59 & - & 17 \\
\hline 5 & $\mathrm{PtO}_{2}$ & - & 1 & 5 & 17 & 77 & - \\
\hline 6 & $\mathrm{PtO}_{2}$ & $\mathrm{HClO}_{4}$ & 1 & 1 & 95 & - & - \\
\hline
\end{tabular}

a) $40 \mathrm{mg}$, b) $420 \mathrm{mg}$.

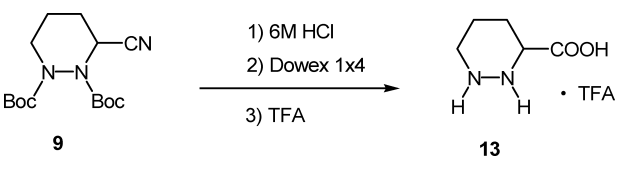

Chart 4

afforded the desired 3-cyanohexahydropyridazine (9) in 95\% yield as the sole product (entry 6). 9 was obtained in $59 \%$ yield together with 12 in $17 \%$ yield using a $10 \% \mathrm{Pd}-\mathrm{C}$ catalyst under similar conditions (entry 4).

In order to convert into the desired Piz, the deprotection of the $N$-Boc group and hydrolysis of the 3-cyanohexahydropyridazine (9) were carried out (Chart 4). Refluxing 9 in $6 \mathrm{M}$ $\mathrm{HCl}$ for $24 \mathrm{~h}$, followed by the treatment with an ion-exchange resin (Dowex $1 \times 4$ ), and then the addition of trifluoroacetic acid (TFA) furnished the desired Piz $\mathbf{1 3}$ in 93\% yield. The ${ }^{1} \mathrm{H}-\mathrm{NMR}$ spectral data of $\mathbf{1 3}$ was in good agreement with that of the known optically active compound in the literature. ${ }^{16)}$

Synthesis of 5-Substituted Piperidazine-3-carboxylic Acids We next planned the synthesis of the 5-substituted piperidazine-3-carboxylic acids through the aza-DA reaction between the Danishefsky reagent (1-methoxy-3-trimethylsilyloxy-1,3-butadiene) and azodicarboxylate. The aza-DA reaction of 3-trimethylsilyloxy-1,3-butadiene (14) with $\mathbf{4}$ in dry $\mathrm{CH}_{2} \mathrm{Cl}_{2}$, followed by the treatment with TMSCN in the presence of $\mathrm{BF}_{3} \cdot \mathrm{OEt}_{2}$ as a Lewis acid at $-40^{\circ} \mathrm{C}$, and then $\mathrm{NaHCO}_{3}$ hydrolysis, successfully gave the 3-cyano-5-oxohexahydropyridazine (17) in $94 \%$ yield in one-pot via the intermediates $\mathbf{1 5}$ and 16. The $\mathrm{NaBH}_{4}$ reduction of $\mathbf{1 7}$ in $\mathrm{EtOH}$ at $-20{ }^{\circ} \mathrm{C}$ gave a mixture of the 5-hydroxy derivatives cis-18 and trans-19 in the ratio of $72: 28$ with a $95 \%$ yield, which could be easily separated by silica gel column chromatography. This $\mathrm{NaBH}_{4}$ reduction quickly proceeded at room temperature giving 18 and 19 , however, the selectivity of the re- duction decreased. The lithium tri-tert-butoxyaluminumhydride reduction of $\mathbf{1 7}$ in tetrahydrofuran (THF) at $-20{ }^{\circ} \mathrm{C}$ produced 18 and 19 in almost a similar ratio and 96\% yield. The hydride reduction seemed to occur by the apparent less hindered attack on the carbonyl group at the C-5 position of the most stable quasi-chair conformer of the 5-oxohexahydropyridazine ring $17 \mathrm{~A}$, which is more favored than $17 \mathrm{~B}$ due to the steric hindrance of the two Boc groups as shown in Chart 6 . Therefore, the stereochemistry of the cyano and hydroxy groups in the major isomer seems to be cis, although specific evidence for this isomer is not available. This stereochemistry was finally determined by conversion into the 5hydroxy Piz from the major $c i$ s-isomer.

Both isomers 18 and 19 were heated in a refluxing mixed solution of $6 \mathrm{M} \mathrm{HCl}$ and $\mathrm{AcOH}$ for $24 \mathrm{~h}$ to afford the corresponding acids 20 and $\mathbf{2 1}$, which were immediately converted into the $N$-dinitrophenyl (DNP) derivatives $\mathbf{2 2}$ and $\mathbf{2 3}$ by the reaction with 1-fluoro-2,4-dinitrobenzene in 92 and $72 \%$ yields, respectively. The ${ }^{1} \mathrm{H}-\mathrm{NMR}$ spectral data of the cis-DNP derivatives 22 was in complete agreement with that of $(3 S, 5 S)$-1-DNP-5-OH-Piz in the literature. ${ }^{21)}$

Both of the 5-hydroxy enantiomers 18 and 19 were chlorinated using the Mitsunobu ${ }^{22)}$ reaction, which is well known as the stereospecific inversion of the hydroxy group into the chloro group. The cis-5-chlorohexahydropyridazine (25) was produced by the reaction of 19 with $\mathrm{PPh}_{3}$ and $\mathrm{CCl}_{4}$ in THF in $60 \%$ yield. Similarly, the trans-derivative $\mathbf{2 4}$ was obtained from the corresponding $\mathbf{1 8}$ in $70 \%$ yield, and then hydrolyzed with $6 \mathrm{M} \mathrm{HCl}$ to give the pyridazinecarboxylic acid (26), which was transformed into the DNP derivative 27 without isolation in $81 \%$ yield. The ${ }^{1} \mathrm{H}-\mathrm{NMR}$ spectral data of the trans-DNP derivatives $\mathbf{2 7}$ was in accord with that reported for the optically active compound.

Optically Active Piperidazine-3-carboxylic Acids Finally, we achieved the asymmetric synthesis of both enan- 


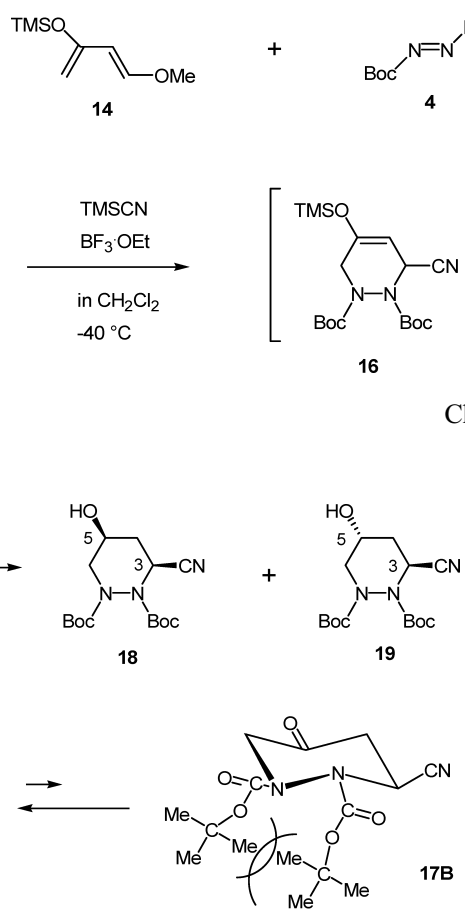

Chart 6

tiomers of the Piz from the 1,3-dienes and optically active azodicarboxylate as the starting material by the previously described method. While several reports ${ }^{14-17,23,24)}$ on the syntheses of the optically active Piz are known, these preparations remain much less explored regarding the synthetic steps and the yields for the preparation of both enantiomers. The treatment of 1-methoxy-1,3-diene (3) with di-(-)-menthyl azodicarboxylate (28) in dry $\mathrm{CH}_{2} \mathrm{Cl}_{2}$ at room temperature, followed by the addition of TMSCN in the presence of $\mathrm{BF}_{3} \cdot \mathrm{OEt}_{2}$ or $\mathrm{TiCl}_{4}$ at $-40{ }^{\circ} \mathrm{C}$ gave the desired 3-cyano1,2,3,6-tetrahydropyridazine (29) as a mixture of the two diastereomers in excellent yields, which were not able to be separated. The $\mathrm{PtO}_{2}$ catalytic hydrogenation of the olefin moiety in 29 in the presence of $70 \% \mathrm{HClO}_{4}$ gave the $(R)$ form 30 and $(S)$-form 31 in 42 and $40 \%$ yields, respectively. The diastereomers $\mathbf{3 0}$ and $\mathbf{3 1}$ could be easily separated by silica gel column chromatography. Transformation from the $(S)$-form 31 into the $(R)$-form $\mathbf{3 0}$ under basic conditions was found. The catalytic hydrogenation of $\mathbf{2 9}$ gave a mixture of 30 and 31, epimerization of which with 1,8-diazabicyclo[5.4.0] undec-7-ene (DBU) in refluxing EtOH for $2 \mathrm{~h}$ finally afforded the mixture of $\mathbf{3 0}$ and $\mathbf{3 1}$ in 50 and $11 \%$ isolated yields, respectively. The hydrolysis of the $(R)$-form $\mathbf{3 0}$ with $6 \mathrm{M} \mathrm{HCl}$, followed by purification using an ion-exchange resin (Dowex $1 \times 4$ ), and then the addition of TFA gave the optically pure Piz $32\left\{\mathrm{mp} 145-147^{\circ} \mathrm{C},[\alpha]_{\mathrm{D}}^{22}-11.6\right.$ $(c=0.97, \mathrm{MeOH})\}$ in $95 \%$ yield. The melting point and the optical rotation of the product were in good agreement with those already reported $(3 R)$-Piz $\left\{\right.$ lit. ${ }^{14)} \mathrm{mp} 147-149^{\circ} \mathrm{C}$, $\left.[\alpha]_{\mathrm{D}}^{22}-12.0(c=1, \mathrm{MeOH})\right\}$. Similarly, 33 mp 145 $\left.147^{\circ} \mathrm{C},[\alpha]_{\mathrm{D}}^{22}+11.6(c=0.97, \mathrm{MeOH})\right\}$ was obtained from the $(S)$-form 31 in $95 \%$ yield. Thus, the absolute configuration of the levorotatory Piz 32 and its precursor Piz was assigned the $(S)$-configuration $\left\{\right.$ lit. ${ }^{16)} \mathrm{mp} 149-151^{\circ} \mathrm{C},[\alpha]_{\mathrm{D}}^{22}$ $+11.1(c=0.98, \mathrm{MeOH})\}$.

\section{Conclusion}

In this study, we established the short-step preparation of the racemic unsubstituted, 5-hydroxy and 5-chloro Piz, and succeeded in the preparation of both enantiomers of the optically active Piz in three steps with $35 \%$ overall yields through the DA reaction and cyanation.

\section{Experimental}

Melting points were measured on a Yanagimoto micro melting point hot stage apparatus and are uncorrected. IR spectra were determined with a Horiba FT-720 spectrometer. Mass spectra (MS) and HR-MS were recorded on a JEOL JMS-DX300 instrument. NMR spectra were determined with a JEOL EX-90A (90 MHz) or a JEOL JNM-GSX $400(400 \mathrm{MHz})$ spectrometer in $\mathrm{CDCl}_{3}$, DMSO- $d_{6}$ or $\mathrm{D}_{2} \mathrm{O}$ using tetramethylsilane as internal standard and $J$ values are given in Hz. Microanalyses were performed in the Microanalytical Laboratory in this Faculty.

Starting 2,4-Dienes and Azodicarboxylate Methy pentadienate (1) ${ }^{25)}$ penta-2,4-dienenitrile $(\mathbf{2})^{26)}$ and di-tert-butyl azodicarboxylate $(\mathbf{4})^{27)}$ were prepared by the reported methods.

General Procedure for the Diels-Alder Reaction of 1,3-Diene with Azocarboxylate 1,3 -Butadiene $(\mathbf{1}-\mathbf{3}, 10 \mathrm{mmol})$ was added to a solution of di-tert-butyl azodicarboxylate $(4,2.30 \mathrm{~g}, 10 \mathrm{mmol})$ in an appropriate solvent $(10 \mathrm{ml})$. The mixture was refluxed or stirred for $2-72 \mathrm{~h}$ until disappearance of the starting material, and then evaporated in vacuo. The resulting residue was purified by silica gel chromatography to give 5-7.

Di-tert-butyl 3-Methyl 1,2,3,6-Tetrahydropyridazine-1,2,3-tricarboxylate (5) The reaction was carried out in refluxing benzene for $72 \mathrm{~h}$. Colorless prisms, $\mathrm{mp} 100-103{ }^{\circ} \mathrm{C}$ (from hexane). MS $m / z 342\left(\mathrm{M}^{+}\right)$. IR (KBr) $\mathrm{cm}^{-1}: 1759,1697(\mathrm{C}=\mathrm{O}) .{ }^{1} \mathrm{H}-\mathrm{NMR}\left(\mathrm{CDCl}_{3}\right) \delta: 1.48(18 \mathrm{H}, \mathrm{s}, t-\mathrm{Bu} \times 2), 3.74$ (3H, s, 3-COOMe), 3.56-3.92 and 4.24-4.52 (each $\left.1 \mathrm{H}, \mathrm{m}, 6-\mathrm{H}_{2}\right), 5.07-$ $5.40(1 \mathrm{H}, \mathrm{m}, 3-\mathrm{H}), 5.87-6.01(2 \mathrm{H}, \mathrm{m}, 4-, 5-\mathrm{H}) .{ }^{13} \mathrm{C}-\mathrm{NMR}\left(\mathrm{CDCl}_{3}\right) \delta: 28.21$ (q), 28.24 (q), 41.5 (t), 52.3 (q), 55.5 (d), 80.7 (s), 82.0 (s), 122.3 (d), 125.5 (d), 153.9 (s), 154.4 (s), 169.1 (s). Anal. Calcd for $\mathrm{C}_{16} \mathrm{H}_{26} \mathrm{~N}_{2} \mathrm{O}_{6}: \mathrm{C}, 56.13 ; \mathrm{H}$, 7.65; N, 8.18. Found: C, 56.12; H, 7.48; N, 8.26.

Di-tert-butyl 3-Cyano-1,2,3,6-tetrahydropyridazine-1,2-dicarboxylate (6) The reaction was carried out in refluxing benzene for $60 \mathrm{~h}$. Colorless needles, mp 95-96 ${ }^{\circ} \mathrm{C}$ (from hexane). MS $m / z 309\left(\mathrm{M}^{+}\right)$. IR $(\mathrm{KBr}) \mathrm{cm}^{-1}$ : $2239(\mathrm{CN}), 1724,1701(\mathrm{C}=\mathrm{O}) .{ }^{1} \mathrm{H}-\mathrm{NMR}\left(\mathrm{CDCl}_{3}\right) \delta: 1.48$ and 1.50 (total $9 \mathrm{H}$, intensity ratio $3: 4$, each $\mathrm{s}, t-\mathrm{Bu}), 1.51(9 \mathrm{H}, \mathrm{s}, t-\mathrm{Bu}), 3.50-3.89$ and $4.41-4.72\left(2 \mathrm{H}, \mathrm{m}, 6-\mathrm{H}_{2}\right), 5.19-5.57(1 \mathrm{H}, \mathrm{br}, 3-\mathrm{H}), 5.63-5.93(1 \mathrm{H}, \mathrm{br}, 4-$ H), $5.93-6.22(1 \mathrm{H}, \mathrm{br}, 5-\mathrm{H}) .{ }^{13} \mathrm{C}-\mathrm{NMR}\left(\mathrm{CDCl}_{3}\right) \delta: 27.9(\mathrm{q}), 28.0$ and 28.2 (each q), 42.1 (t), 43.0 (d), 81.6 and 82.3 (each s), 83.0 (s), 83.5 and 83.7 (each s), 115.3 (s), 119.3 and 119.6 (each d), 128.4 and 129.1 (each d), 152.9 (s), 153.6 and 154.2 (each s). Anal. Calcd for $\mathrm{C}_{15} \mathrm{H}_{23} \mathrm{~N}_{3} \mathrm{O}_{4}$ : C, 58.24; H, 7.49; N, 13.58. Found: C, 58.04; H, 7.35; N, 13.82 .

Di-tert-butyl 3-Methoxy-1,2,3,6-tetrahydropyridazine-1,2-dicarboxylate (7) The reaction was carried out in $\mathrm{CH}_{2} \mathrm{Cl}_{2}$ at room temperature for $2 \mathrm{~h}$. Colorless oil. MS m/z $314\left(\mathrm{M}^{+}\right)$. IR (neat) $\mathrm{cm}^{-1}: 1706(\mathrm{C}=\mathrm{O}) .{ }^{1} \mathrm{H}-\mathrm{NMR}$ $\left(\mathrm{CDCl}_{3}\right) \delta$ : 1.49 and 1.50 (each $9 \mathrm{H}, \mathrm{s}, t-\mathrm{Bu} \times 2$ ), 3.49 and 3.53 (total $3 \mathrm{H}$, intensity ratio $4: 1$, each $\mathrm{s}, \mathrm{OMe}), 3.55-3.83,4.31$ and $4.49(1 \mathrm{H}, \mathrm{m}$, total $1 \mathrm{H}$, intensity ratio $1: 4, \mathrm{~d}, J=18.7 \mathrm{~Hz}$ and $\left.\mathrm{dd}, J=18.0,2.9 \mathrm{~Hz}, 6-\mathrm{H}_{2}\right), 5.25-5.66$ $(1 \mathrm{H}, \mathrm{br}, 3-\mathrm{H}), 5.77-6.15(2 \mathrm{H}, \mathrm{m}, 4-, 5-\mathrm{H}) .{ }^{13} \mathrm{C}-\mathrm{NMR}\left(\mathrm{CDCl}_{3}\right) \delta: 28.26$ (q), 28.34 (q), 41.7 and 43.6 (each t), $56.2(\mathrm{q}), 80.3$ (d), 80.8 and 81.0 (each s), 81.6 (s), 123.8 and 124.3 (each d), 127.2 and 127.7 (each d), 154.5 (s), 154.9 


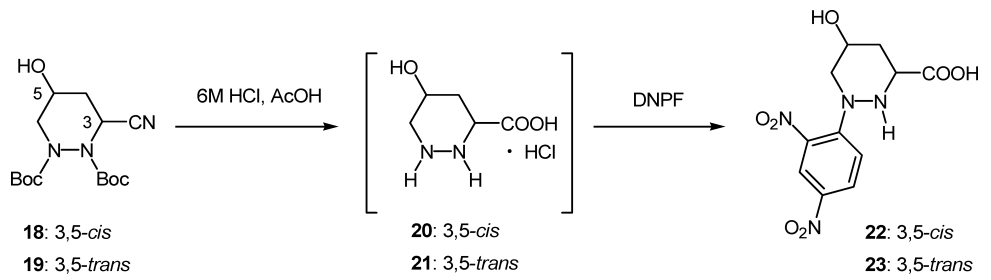

Chart 7

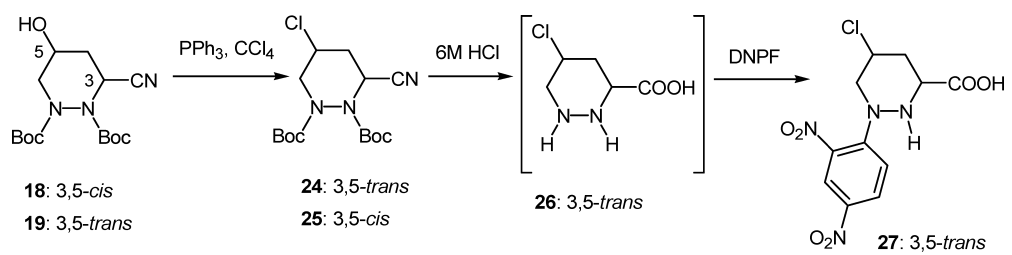

Chart 8
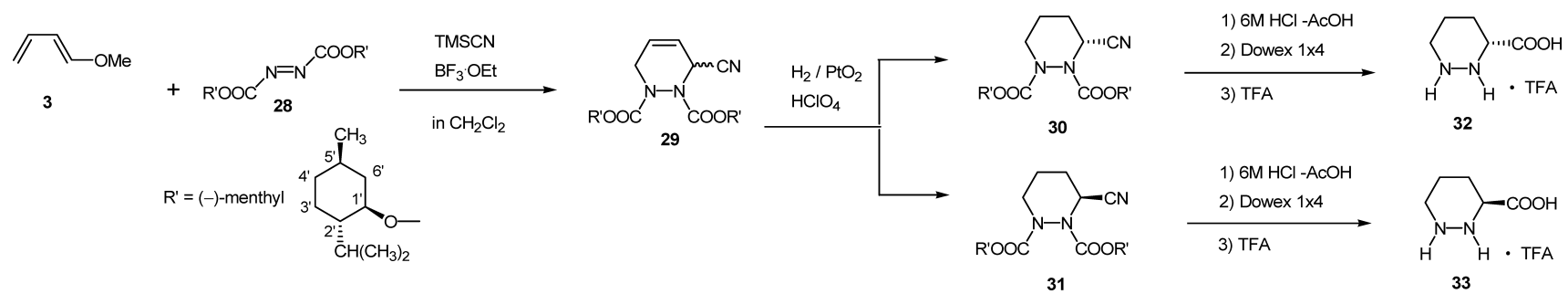

Chart 9

(s). HR-MS m/z: 314.1842 (Calcd for $\mathrm{C}_{15} \mathrm{H}_{26} \mathrm{~N}_{2} \mathrm{O}_{5}: 314.1842$ ).

Cyanation of 3-Methoxy-1,2,3,6-tetrahydropyridazine (7) TMSCN $(2.00 \mathrm{ml}, 15 \mathrm{mmol})$ was added to a solution of 7 (3.14 g, $10 \mathrm{mmol})$ in $\mathrm{CH}_{2} \mathrm{Cl}_{2}$ $(40 \mathrm{ml})$ at $-40{ }^{\circ} \mathrm{C}$ under argon atmosphere. $\mathrm{BF}_{3} \cdot$ OEt or $\mathrm{TiCl}_{4}(5 \mathrm{mmol})$ in $\mathrm{CH}_{2} \mathrm{Cl}_{2}(10 \mathrm{ml})$ was added to the reaction mixture. The mixture was stirred under the conditions for $5 \mathrm{~h}\left(\mathrm{TiCl}_{4}: 1 \mathrm{~h}\right) .2 \% \mathrm{NaHCO}_{3}$ solution was added to the mixture, and the aqueous mixture was vigorously stirred at room temperature for $1 \mathrm{~h}$. The mixture was extracted with $\mathrm{CHCl}_{3}(100 \mathrm{ml} \times 3)$. The organic layer was washed with water $(200 \mathrm{ml})$, dried over anhydrous $\mathrm{Na}_{2} \mathrm{SO}_{4}$ and evaporated in vacuo. The resulting residue was chromatographed on silica gel using AcOEt-hexane to give 6.

$\mathrm{BF}_{3} \cdot \mathrm{OEt}: 2.90 \mathrm{~g}, 94 \%$.

$\mathrm{TiCl}_{4}: 2.83 \mathrm{~g}, 92 \%$

One-Pot Synthesis of 3-Cyano-1,2,3,6-tetrahydropyridazine (6) To a solution of azodicarboxylate $(4,2.30 \mathrm{~g}, 10 \mathrm{mmol})$ in $\mathrm{CH}_{2} \mathrm{Cl}_{2}(10 \mathrm{ml})$ was added 1-methoxy-1,3-butadiene $(3,1.11 \mathrm{ml}, 11 \mathrm{mmol})$ or 1-trimethoxysilyloxy-1,3-butadiene $(\mathbf{8}, 1.93 \mathrm{ml}, 11 \mathrm{mmol})$ at room temperature. After stirring for $30 \mathrm{~min}$, a solution of TMSCN $(2.00 \mathrm{ml}, 15 \mathrm{mmol})$ in $\mathrm{CH}_{2} \mathrm{Cl}_{2}(30 \mathrm{ml})$ and then a solution of $\mathrm{BF}_{3} \cdot \mathrm{OEt}(0.63 \mathrm{ml}, 5 \mathrm{mmol})$ in $\mathrm{CH}_{2} \mathrm{Cl}_{2}(10 \mathrm{ml})$ were added to the stirring mixture at $-40{ }^{\circ} \mathrm{C}$ under argon atmosphere. The mixture was stirred under the conditions until disappearance of the starting material. $2 \%$ $\mathrm{NaHCO}_{3}$ solution $(100 \mathrm{ml})$ was added to the mixture, and the aqueous mixture was vigorously stirred at room temperature for $1 \mathrm{~h}$. The mixture was extracted with $\mathrm{CHCl}_{3}(100 \mathrm{ml} \times 3)$. The organic layer was washed with water $(200 \mathrm{ml})$, dried over anhydrous $\mathrm{Na}_{2} \mathrm{SO}_{4}$ and evaporated in vacuo. The resulting residue was chromatographed on silica gel using AcOEt-hexane to give 6

91\% yield from 3 .

$80 \%$ yield from $\mathbf{8}$.

Hydrogenation of 3-Cyano-1,2,3,6-tetrahydropyridazine (6) A mixture of $6(0.93 \mathrm{~g}, 3 \mathrm{mmol})$ and $10 \% \mathrm{Pd}-\mathrm{C}(40 \mathrm{mg})$ or $\mathrm{PtO}_{2}(90 \mathrm{mg})$ in $\mathrm{EtOH}$ $(8 \mathrm{ml})$ was shaken in $\mathrm{H}_{2}$ ( $1 \mathrm{~atm}$ pressure) at room temperature for $1-10 \mathrm{~h}$ (until disappearance of the starting material). After removal of the catalyst, the filtrate was evaporated in vacuo. The resulting residue was chromatographed on silica gel using AcOEt-hexane to give 9, 10 and 12.

Hydrogenation of 3-Cyano-1,2,3,6-tetrahydropyridazine (6) with $70 \%$ $\mathrm{HClO}_{4}$ A mixture of $\mathbf{6}(0.93 \mathrm{~g}, 3 \mathrm{mmol}), 10 \% \mathrm{Pd}-\mathrm{C}(40 \mathrm{mg})$ or $\mathrm{PtO}_{2}$ $(90 \mathrm{mg})$ and $70 \% \mathrm{HClO}_{4}(2$ drops $)$ in $\mathrm{EtOH}(8 \mathrm{ml})$ was shaken in $\mathrm{H}_{2}(1 \mathrm{~atm}$ pressure) at room temperature for $1 \mathrm{~h}$. After removal of the catalyst, $\mathrm{NaHCO}_{3}$ saturated aqueous solution $(5 \mathrm{ml})$ was added to the mixture. The aqueous mixture was extracted with AcOEt $(30 \mathrm{ml} \times 3)$. The combined organic layer was washed with brine $(20 \mathrm{ml} \times 2)$, dried over anhydrous $\mathrm{Na}_{2} \mathrm{SO}_{4}$ and evaporated in vacuo. The resulting residue was chromatographed on silica gel using AcOEt-hexane to give $\mathbf{9}$ and $\mathbf{1 2}$

Di-tert-butyl 3-Cyanohexahydropyridazine-1,2-dicarboxylate (9) Coleorless prisms mp $104-105^{\circ} \mathrm{C}$ (from hexane). MS $m / z 311\left(\mathrm{M}^{+}\right)$. IR $\left.(\mathrm{KBr}) \mathrm{cm}^{-1}: 2241 \mathrm{CN}\right), 1697(\mathrm{C}=\mathrm{O}) .{ }^{1} \mathrm{H}-\mathrm{NMR}\left(\mathrm{CDCl}_{3}\right) \delta: 1.48$ and 1.50 (each $9 \mathrm{H}, \mathrm{s}, t-\mathrm{Bu}), 1.67-1.73$ and $1.86-2.05\left(1 \mathrm{H}, \mathrm{m}, 3 \mathrm{H}, \mathrm{m}, 5-\mathrm{H}_{2}, 4-\mathrm{H}_{2}\right)$, [2.82 and $2.87-3.11$ (total $1 \mathrm{H}$, intensity ratio $2: 1, \mathrm{t}, J=11.8 \mathrm{~Hz}, \mathrm{~m}$ ), 3.94, 4.10 and 4.28 (total $1 \mathrm{H}$, intensity ratio $1: 6: 20, \mathrm{~d}, J=12.8 \mathrm{~Hz}, \mathrm{~d}, J=11.9 \mathrm{~Hz}$, d, $J=13.5 \mathrm{~Hz}$ ), 6- $\mathrm{H}_{2}$ ], 4.65-4.80, 5.20-5.22 and 5.22-5.40 (total $1 \mathrm{H}$, intensity ratio $1: 3: 10$, each br, 3-H). ${ }^{13} \mathrm{C}-\mathrm{NMR}\left(\mathrm{CDCl}_{3}\right) \delta: 20.1(\mathrm{t}), 27.1(\mathrm{t})$, 28.0 (q), 28.2 (q), 43.0 (t), 43.7 (d), 81.8 (s), 82.6 (s), 116.5 (s), 152.8 (s), 153.6 (s). Anal. Calcd for $\mathrm{C}_{15} \mathrm{H}_{25} \mathrm{~N}_{3} \mathrm{O}_{4}$ : C, 57.86; H, 8.09; N, 13.49. Found: C, 58.01; H, 8.00; N, 13.36.

Di-tert-butyl 3-Cyano-1,2,5,6-tetrahydropyridazine-1,2-dicarboxylate (10) Colorless oil. MS m/z $209\left[(\mathrm{MH}-\mathrm{Boc})^{+}\right], 109\left[\left(\mathrm{MH}_{2}-2 \mathrm{Boc}\right)^{+}\right]$. IR (neat) $\mathrm{cm}^{-1}: 2231(\mathrm{CN}), 1720(\mathrm{C}=\mathrm{O}) .{ }^{1} \mathrm{H}-\mathrm{NMR}\left(\mathrm{CDCl}_{3}\right) \delta: 1.48$ and 1.55 (total $18 \mathrm{H}$, intensity ratio $9: 11$, each $\mathrm{s}, t-\mathrm{Bu}$ ), [2.17 and 2.21 (total $1 \mathrm{H}$, intensity ratio $1: 1$, each dd, $\left.J=4.8,4.8 \mathrm{~Hz}), 2.41-2.57(1 \mathrm{H}, \mathrm{m}) 5-\mathrm{H}_{2}\right], 2.98-$ 3.22 and $4.29-4.48\left(\right.$ each $\left.1 \mathrm{H}, \mathrm{m}, 6-\mathrm{H}_{2}\right), 6.04-6.18(1 \mathrm{H}, \mathrm{dd}, J=4.8,4.8 \mathrm{~Hz}$, 4-H). ${ }^{13} \mathrm{C}-\mathrm{NMR}\left(\mathrm{CDCl}_{3}\right) \delta: 22.7(\mathrm{t}), 28.0(\mathrm{q}), 28.1(\mathrm{q}), 41.5(\mathrm{t}), 82.3(\mathrm{~s})$, 84.8 (s), 113.9 (s), 115.1 (s), 128.0 (d), 150.7 (s), 154.0 (s). HR-MS m/z: 209.1160 (Calcd for $\mathrm{C}_{10} \mathrm{H}_{15} \mathrm{~N}_{3} \mathrm{O}_{2}: 209.1164$ ), 109.0642 (Calcd for $\mathrm{C}_{5} \mathrm{H}_{7} \mathrm{~N}_{3}$ : 109.0640).

Di-tert-butyl 3-(tert-Butoxycarbonylaminomethyl)hexahydropyri- 
dazine-1,2-dicarboxylate (12) Colorless oil. MS $m / z 415\left(\mathrm{M}^{+}\right)$. IR (neat) $\mathrm{cm}^{-1}: 3423(\mathrm{NH}), 1722,1693(\mathrm{C}=\mathrm{O}) .{ }^{1} \mathrm{H}-\mathrm{NMR}\left(\mathrm{CDCl}_{3}\right) \delta: 1.38-1.59$ and $1.66-1.83\left(28 \mathrm{H}, \mathrm{m}\right.$ and $\left.3 \mathrm{H}, \mathrm{m}, t-\mathrm{Bu} \times 3,4-\mathrm{H}_{2}, 5-\mathrm{H}_{2}\right), 2.77-3.48(3 \mathrm{H}, \mathrm{m}, 3-$ $\left.\mathrm{H}, 6-\mathrm{H}_{2}\right), 3.83-4.45\left(2 \mathrm{H}, \mathrm{m}, \mathrm{CH}_{2} \mathrm{NHBoc}\right), 4.70-4.95,4.95-5.47$ and $5.47-5.85$ (total $1 \mathrm{H}$, intensity ratio $1: 10: 4$, each br, $\mathrm{NH}$ ). ${ }^{13} \mathrm{C}-\mathrm{NMR}$ $\left(\mathrm{CDCl}_{3}\right) \delta: 19.3$ and 19.8 (each t), 23.9, 24.1 and 24.8 (each t), 28.2 (q), 28.3 (q), 28.4 (q), 39.6 and 40.1 (each t), 42.8 and 45.5 (each t), 52.5 and 54.4 (each d), 78.9 (s), 79.1 (s), 81.5 (s), 154.0 (s), 155.1 (s), 156.0 (s). HRMS $m / z: 415.2628$ (Calcd for $\mathrm{C}_{20} \mathrm{H}_{37} \mathrm{~N}_{3} \mathrm{O}_{6}: 415.2682$ ).

( \pm ) Hexahydropyridazine-3-carboxylic Acid Trifluoroacetic Acid (13) A mixture of $9(621 \mathrm{mg}, 2 \mathrm{mmol})$ and $6 \mathrm{M} \mathrm{HCl}(20 \mathrm{ml})$ was refluxed for $24 \mathrm{~h}$ under argon atmosphere, and then evaporated in vacuo. The residue was desalted by ion-exchange chromatography on a Dowex $1 \times 4$ (50-100 mesh, $\mathrm{CH}_{3} \mathrm{COO}^{-}$form) column with water. After addition of $\mathrm{AcOH}(1 \mathrm{ml})$ to the eluent, the eluent was concentrated to dryness. $10 \% \mathrm{CF}_{3} \mathrm{COOH}$ was added to the obtained residue, and the mixture was evaporated in vacuo to give the crude trifluoroacetate, which was recrystallized from EtOH-AcOEt. White powder, $454 \mathrm{mg}, 93 \%$ yield, mp $146-147^{\circ} \mathrm{C}$. MS (FAB) $\mathrm{m} / \mathrm{z} 131$ $\left[(\mathrm{MH}-\mathrm{TFA})^{+}\right]$. IR $(\mathrm{KBr}) \mathrm{cm}^{-1}: 3292,3080,2970(\mathrm{OH}, \mathrm{NH}), 1724,1664$ $(\mathrm{C}=\mathrm{O}) .{ }^{1} \mathrm{H}-\mathrm{NMR}\left(\mathrm{D}_{2} \mathrm{O}\right) \delta: 1.81-1.90,1.90-1.95$ and $2.07-2.16(2 \mathrm{H}, \mathrm{m}$, $\left.1 \mathrm{H}, \mathrm{m}, 1 \mathrm{H}, \mathrm{m}, 4-\mathrm{H}_{2}, 5-\mathrm{H}_{2}\right), 3.12-3.18$ and $3.25-3.31$ (each $\left.1 \mathrm{H}, \mathrm{m}, 6-\mathrm{H}_{2}\right)$, $3.92(1 \mathrm{H}$, dd, $J=8.0,4.3 \mathrm{~Hz}, 3-\mathrm{H}),{ }^{13} \mathrm{C}-\mathrm{NMR}\left(\mathrm{D}_{2} \mathrm{O}\right) \delta: 20.1(\mathrm{t}), 25.1(\mathrm{t}), 45.7$ (t), $56.6(\mathrm{~d}), 117.1\left(\mathrm{q}_{\mathrm{F}},{ }^{1} J_{\mathrm{CF}}=291.7 \mathrm{~Hz}\right), 163.7\left(\mathrm{q}_{\mathrm{F}},{ }^{2} J_{\mathrm{CF}}=35.1 \mathrm{~Hz}\right), 174.6(\mathrm{~s})$. Anal. Calcd for $\mathrm{C}_{17} \mathrm{H}_{11} \mathrm{~F}_{3} \mathrm{~N}_{2}$ : C, 34.43; H, 4.54; N, 11.47. Found: $\mathrm{C}, 34.52$; $\mathrm{H}, 4.43 ; \mathrm{N}, 11.27$.

Di-tert-butyl 3-Cyano-5-oxohexahydropyridazine-1,2-dicarboxylate (17) To a solution of azodicarboxylate $(4,2.30 \mathrm{~g}, 10 \mathrm{mmol})$ in $\mathrm{CH}_{2} \mathrm{Cl}_{2}$ (10 $\mathrm{ml})$ was added 1-methoxy-3-(trimethylsilyloxy)-1,3-butadiene (14, $90 \%$, $2.38 \mathrm{ml}, 11 \mathrm{mmol}$ ) at room temperature, and the mixture was stirred for $30 \mathrm{~min}$. A solution of TMSCN $(2.00 \mathrm{ml}, 15 \mathrm{mmol})$ in $\mathrm{CH}_{2} \mathrm{Cl}_{2}(30 \mathrm{ml})$ and then a solution of $\mathrm{BF}_{3} \cdot \mathrm{OEt}(0.63 \mathrm{ml}, 5 \mathrm{mmol})$ in $\mathrm{CH}_{2} \mathrm{Cl}_{2}(10 \mathrm{ml})$ were added to the stirring mixture at $-40{ }^{\circ} \mathrm{C}$ under argon atmosphere. The mixture was stirred under the conditions for $24 \mathrm{~h} .2 \% \mathrm{NaHCO}_{3}$ aqueous solution $(100 \mathrm{ml})$ was added to the mixture, and the aqueous mixture was vigorously stirred at room temperature for $1 \mathrm{~h}$. The mixture was extracted with $\mathrm{CHCl}_{3}$ $(100 \mathrm{ml} \times 3)$. The organic layer was washed with water $(200 \mathrm{ml})$, dried over anhydrous $\mathrm{Na}_{2} \mathrm{SO}_{4}$ and evaporated in vacuo. The resulting residue was chromatographed on silica gel using $\mathrm{CHCl}_{3}-\mathrm{MeOH}(100: 1)$ to give $\mathbf{1 7}(3.06 \mathrm{~g}$, $94 \%$ yield). Colorless needles, $\mathrm{mp} 129-130^{\circ} \mathrm{C}$ (from benzene-hexane). MS (FAB) $m / z 326\left(\mathrm{MH}^{+}\right)$. IR ( $\left.\mathrm{KBr}\right) \mathrm{cm}^{-1}: 2247(\mathrm{CN}), 1747,1723(\mathrm{C}=\mathrm{O})$ ${ }^{1} \mathrm{H}-\mathrm{NMR}\left(\mathrm{CDCl}_{3}\right) \delta: 1.50,1.51$ and 1.55 (total $18 \mathrm{H}$, intensity ratio $1: 2: 7$, each $\mathrm{s}, t-\mathrm{Bu} \times 2), 2.84-2.98\left(2 \mathrm{H}, \mathrm{m}, 4-\mathrm{H}_{2}\right), 3.57-4.04,4.45-4.62$ and 4.74 (total $2 \mathrm{H}$, intensity ratio $10: 3: 7, \mathrm{~m}, \mathrm{br}, \mathrm{d}, J=18.1 \mathrm{~Hz}, 6-\mathrm{H}_{2}$ ), 4.98 5.23 and $5.23-5.53$ (total $1 \mathrm{H}$, intensity ratio $3: 7, \mathrm{~m}, 3-\mathrm{H}$ ). ${ }^{13} \mathrm{C}-\mathrm{NMR}$ $\left(\mathrm{CDCl}_{3}\right) \delta: 27.8$ and 28.0 (each q), 28.1 (q), 39.9 and 40.1 (each t), 43.9 and 45.8 (each d), 55.8 and 56.0 (each t), $83.5(\mathrm{~s}), 84.0(\mathrm{~s}), 116.3(\mathrm{~s}), 152.2(\mathrm{~s})$, 153.4 (s), 199.4 (s). Anal. Calcd for $\mathrm{C}_{15} \mathrm{H}_{23} \mathrm{~N}_{3} \mathrm{O}_{5}:$ C, 55.37; H, 7.13; N, 12.91. Found: C, 55.51; H, 7.00; N, 13.07 .

$\mathrm{NaBH}_{4}$ Reduction of 3-Cyano-5-oxohexahydropyridazine (17) $\mathrm{NaBH}_{4}$ $(567 \mathrm{mg}, 15 \mathrm{mmol})$ was added to a stirred solution of $17(3.25 \mathrm{~g}, 10 \mathrm{mmol})$ in $\mathrm{EtOH}(150 \mathrm{ml})$ at $-0^{\circ} \mathrm{C}$, and the reaction mixture was stirred until disappearance of the starting material. Cold water $(10 \mathrm{ml})$ was added to the mixture, the aqueous mixture was acidified with $\mathrm{AcOH}$ (the range of the $\mathrm{pH}$ value: 5 -6). The whole mixture was evaporated, and water $(100 \mathrm{ml})$ was added to the residue. The obtained aqueous mixture was extracted with AcOEt $(300 \mathrm{ml} \times 3)$. The combined organic layer was washed with water $(200 \mathrm{ml})$, dried over anhydrous $\mathrm{Na}_{2} \mathrm{SO}_{4}$ and evaporated in vacuo. The resulting residue was chromatographed on silica gel using AcOEt-hexane to give 18 and 19.

$\mathrm{LiAl}(\mathrm{Ot} \text {-Bu })_{3} \mathrm{H}$ Reduction of 3-Cyano-5-oxohexahydropyridazine (17) A solution of $17(3.25 \mathrm{~g}, 10 \mathrm{mmol})$ in dry THF $(70 \mathrm{ml})$ was slowly added to a stirred solution of $\mathrm{LiAl}(\mathrm{Ot}-\mathrm{Bu})_{3} \mathrm{H}(5.09 \mathrm{~g}, 20 \mathrm{mmol})$ in THF $(80 \mathrm{ml})$ at $-20^{\circ} \mathrm{C}$ under argon atmosphere, and the mixture was stirred for $3 \mathrm{~h}$ under the same conditions. An aqueous solution of $\mathrm{NH}_{4} \mathrm{Cl}(1.75 \mathrm{~g})$ in water $(20 \mathrm{ml})$ was slowly added to the mixture, and the aqueous mixture was acidified with $2 \mathrm{M} \mathrm{HCl}$ (the range of the $\mathrm{pH}$ value: $5-6$ ). The obtained precipitate was filtered off, well washed with THF $(100 \mathrm{ml})$. The filtrate was concentrated and extracted with AcOEt $(300 \mathrm{ml} \times 3)$. The combined organic layers were washed with water $(200 \mathrm{ml})$, dried over anhydrous $\mathrm{Na}_{2} \mathrm{SO}_{4}$ and evaporated in vacuo. The resulting residue was chromatographed on silica gel using AcOEt-hexane to give $\mathbf{1 8}$ and $\mathbf{1 9}$.

Di-tert-butyl cis-3-Cyano-5-hydroxyhexahydropyridazine-1,2-dicarboxylate (18) Colorless plates, $\mathrm{mp} 160-162^{\circ} \mathrm{C}$ (from benzene-hexane). MS (FAB) $m / z 328\left(\mathrm{MH}^{+}\right)$. IR (KBr) cm ${ }^{-1}: 3491(\mathrm{OH}), 2242(\mathrm{CN}), 1721$,
$1696(\mathrm{C}=\mathrm{O}) .{ }^{1} \mathrm{H}-\mathrm{NMR}\left(\mathrm{CDCl}_{3}\right) \delta: 1.49$ and 1.52 (total $18 \mathrm{H}$, intensity ratio $2: 3$, each $\mathrm{s}, t$-Bu $\times 2), 2.01$ and $2.16(1 \mathrm{H}$, ddd, $J=14.4,6.6,3.0 \mathrm{~Hz}$ and $1 \mathrm{H}$, dd, $J=14.4,1.4 \mathrm{~Hz}, 4-\mathrm{H}_{2}$ ), $2.58-2.82$ and $2.82-2.98$ (total $1 \mathrm{H}$, intensity ratio $2: 9$, each br, $\mathrm{OH}$ ), 3.02, 3.08-3.39 and 4.34 (total $2 \mathrm{H}$, intensity ratio $\left.5: 2: 7, \mathrm{~d}, J=14.2 \mathrm{~Hz}, \mathrm{~m}, \mathrm{~d}, J=14.2 \mathrm{~Hz}, 6-\mathrm{H}_{2}\right), 4.03-4.22(1 \mathrm{H}, \mathrm{m}, 5-\mathrm{H})$ $5.03-5.09$ and $5.27-5.30$ (total $1 \mathrm{H}$, intensity ratio $2: 7$, each $\mathrm{m}, 3-\mathrm{H}) .{ }^{13} \mathrm{C}$ $\operatorname{NMR}\left(\mathrm{CDCl}_{3}\right) \delta: 27.9(\mathrm{q}), 28.2(\mathrm{q}), 32.6(\mathrm{t}), 39.0$ and $41.2($ each d), $49.4(\mathrm{t})$, $62.1(\mathrm{~d}), 82.4(\mathrm{~s}), 82.7$ (s), $117.4(\mathrm{~s}), 152.7$ (s), 155.2 (s). Anal. Calcd for $\mathrm{C}_{15} \mathrm{H}_{25} \mathrm{~N}_{3} \mathrm{O}_{5}: \mathrm{C}, 55.03 ; \mathrm{H}, 7.70 ; \mathrm{N}, 12.84$. Found: $\mathrm{C}, 55.10 ; \mathrm{H}, 7.52 ; \mathrm{N}$ 12.78 .

Di-tert-butyl trans-3-Cyano-5-hydroxyhexahydropyridazine-1,2-dicarboxylate (19) Colorless prisms, $\mathrm{mp} 103-105^{\circ} \mathrm{C}$ (from benzene-hexane). MS (FAB) $m / z 328\left(\mathrm{MH}^{+}\right)$. IR (KBr) cm ${ }^{-1}: 3498(\mathrm{OH}), 2249(\mathrm{CN}), 1718$ $1687(\mathrm{C}=\mathrm{O}) .{ }^{1} \mathrm{H}-\mathrm{NMR}\left(\mathrm{CDCl}_{3}\right) \delta: 1.48$ and 1.49 (total $18 \mathrm{H}$, intensity ratio $5: 1$, each $\mathrm{s}, t-\mathrm{Bu} \times 2$ ) $, 1.78,2.23$ and $2.27-2.44$ (total $2 \mathrm{H}$, intensity ratio $4: 3: 1$, ddd, $J=16.7,13.1,5.7 \mathrm{~Hz}$, ddd, $J=13.3,2.1,2.1 \mathrm{~Hz}, \mathrm{~m}, 4-\mathrm{H}_{2}$ ), [2.60, $2.66-2.79$ (total $1 \mathrm{H}$, intensity ratio $2: 1$, dd, $J=11.7,11.2 \mathrm{~Hz}, \mathrm{~m}$ ), 4.22 and 4.38 (total $1 \mathrm{H}$, intensity ratio $1: 5, \mathrm{dd}, J=12.6,4.6 \mathrm{~Hz}$ and dd, $J=13.1$, $4.4 \mathrm{~Hz}$ ), $6-\mathrm{H}_{2}$ ], $3.17-3.29$ and $3.49-3.66$ (total $1 \mathrm{H}$, intensity ratio $1: 7$, each br, OH), $4.04-4.15(1 \mathrm{H}, \mathrm{m}, 5-\mathrm{H}), 5.21-5.30$ and $5.30-5.48$ (total $1 \mathrm{H}$, intensity ratio $1: 3$, each br, $3-\mathrm{H}) .{ }^{13} \mathrm{C}-\mathrm{NMR}\left(\mathrm{CDCl}_{3}\right) \delta: 28.0(\mathrm{q}), 28.1$ (q), 35.1 and 35.7 (each t), 43.6 and 45.2 (each d), 49.6 and 51.2 (each t), $62.0(\mathrm{~s}), 82.5(\mathrm{~s}), 83.2(\mathrm{~s}), 116.4(\mathrm{~s}), 152.6$ (s), 153.8 (s). Anal. Calcd for $\mathrm{C}_{15} \mathrm{H}_{25} \mathrm{~N}_{3} \mathrm{O}_{5}: \mathrm{C}, 55.03 ; \mathrm{H}, 7.70 ; \mathrm{N}, 12.84$. Found: $\mathrm{C}, 54.98 ; \mathrm{H}, 7.51 ; \mathrm{N}$, 12.74 .

cis-1-(2,4-Dinitrophenyl)-5-hydroxyhexahydropyridazine-3-carboxylic Acid (22) A solution of cis-18 (981 mg, $3 \mathrm{mmol})$ in $\mathrm{AcOH}(30 \mathrm{ml})$ and $6 \mathrm{M}$ $\mathrm{HCl}(30 \mathrm{ml})$ was heated at $120^{\circ} \mathrm{C}$ (bath temp.) for $24 \mathrm{~h}$ and then evaporated in vacuo. The obtained residue was dissolved in water $(15 \mathrm{ml})$. Saturated $\mathrm{NaHCO}_{3}$ aqueous solution $(15 \mathrm{ml})$ and a solution of 1-fluoro-2,4-dinitrobenzene $(1.15 \mathrm{ml}, 9 \mathrm{mmol})$ in $\mathrm{EtOH}(25 \mathrm{ml})$ were added to the aqueous mixture at $0{ }^{\circ} \mathrm{C}$, the whole mixture $(\mathrm{pH} 7-8)$ was stirred at room temperature for $2 \mathrm{~h}$. After addition of $1 \% \mathrm{NaHCO}_{3}$ aqueous solution $(45 \mathrm{ml})$ at $0{ }^{\circ} \mathrm{C}$, the mixture was washed with ether $(50 \mathrm{ml} \times 2)$, acidified with $2 \mathrm{M} \mathrm{HCl}(\mathrm{pH} 3)$, and then extracted with ether $(50 \mathrm{ml} \times 3)$. The organic layer was washed with brine $(100 \mathrm{ml} \times 4)$, dried over $\mathrm{Na}_{2} \mathrm{SO}_{4}$, and concentrated in vacuo. The residue was chromatographed on silica gel using ether- $\mathrm{MeOH}$ to give 22. Yellow prisms, $\mathrm{mp} 200^{\circ} \mathrm{C}$ (decomp., from EtOH-ether-hexane), $92 \%$ yield. MS $m / z 312\left(\mathrm{M}^{+}\right)$. IR (KBr) cm ${ }^{-1}: 3392(\mathrm{OH}, \mathrm{NH}), 1733,1610(\mathrm{C}=\mathrm{O}) .{ }^{1} \mathrm{H}-$ NMR (DMSO- $\left.d_{6}\right) \delta: 1.32(1 \mathrm{H}$, ddd, $J=12.0,11.9,11.0 \mathrm{~Hz}, 4-\mathrm{H} a x), 2.20$ $(1 \mathrm{H}, \mathrm{ddd}, J=12.0,3.5,3.2 \mathrm{~Hz}, 4-\mathrm{Heq}), 2.80(1 \mathrm{H}, \mathrm{dd}, J=11.0,11.0 \mathrm{~Hz}, 6-$ $\mathrm{H} a x), 3.34(1 \mathrm{H}, \mathrm{ddd}, J=11.9,11.9,3.0 \mathrm{~Hz}, 3-\mathrm{H}), 3.71-3.80(1 \mathrm{H}, \mathrm{m}, 5-\mathrm{H})$, $3.98(1 \mathrm{H}, \mathrm{dd}, J=11.8,4.8 \mathrm{~Hz}, 6-\mathrm{Heq}), 5.09(1 \mathrm{H}, \mathrm{d}, J=11.9 \mathrm{~Hz}, \mathrm{NH}), 5.20$ $5.45(1 \mathrm{H}, \mathrm{br}, \mathrm{OH}), 7.22\left(1 \mathrm{H}, \mathrm{d}, J=9.4 \mathrm{~Hz}, 6^{\prime}-\mathrm{H}\right.$ in $\left.\mathrm{Ph}-\mathrm{H}\right), 8.19(1 \mathrm{H}$, ddd, $J=9.4,2.7,0.5 \mathrm{~Hz}, 5^{\prime}-\mathrm{H}$ in $\left.\mathrm{Ph}-\mathrm{H}\right), 8.33\left(1 \mathrm{H}, \mathrm{dd}, J=2.7,0.5 \mathrm{~Hz}, 3^{\prime}-\mathrm{H}\right.$ in $\mathrm{Ph}-$ $\mathrm{H}), 12.54-13.20(1 \mathrm{H}, \mathrm{br}, \mathrm{COOH}) .{ }^{13} \mathrm{C}-\mathrm{NMR}$ (DMSO- $\left.d_{6}\right) \delta: 36.9(\mathrm{t}), 52.5$ (t), 56.0 (d), 63.7 (d), 115.2 (d), 121.7 (d), 127.2 (d), 136.4 (s), 137.5 (s), 147.1 (s), 171.8 (s). Anal. Calcd for $\mathrm{C}_{11} \mathrm{H}_{12} \mathrm{~N}_{4} \mathrm{O}_{7}: \mathrm{C}, 42.31 ; \mathrm{H}, 3.87 ; \mathrm{N}$, 17.94. Found: C, $42.32 ; \mathrm{H}, 3.92 ; \mathrm{N}, 17.87$.

trans-1-(2,4-Dinitrophenyl)-5-hydroxyhexahydropyridazine-3-carboxylic Acid (23) The title compound was prepared from 19 in a similar manner to that described for 22. Yellow powder, $\mathrm{mp} 164-165^{\circ} \mathrm{C}$ (from EtOH-ether-hexane), $72 \%$ yield. MS $m / z 312\left(\mathrm{M}^{+}\right)$. IR ( $\left.\mathrm{KBr}\right) \mathrm{cm}^{-1}: 3415$ $(\mathrm{OH}, \mathrm{NH}), 1720,1608(\mathrm{C}=\mathrm{O}) .{ }^{1} \mathrm{H}-\mathrm{NMR}\left(\mathrm{DMSO}-d_{6}\right) \delta: 1.70(1 \mathrm{H}, \mathrm{dd}$, $J=11.5,10.8 \mathrm{~Hz}, 4-\mathrm{Hax}), 1.87(1 \mathrm{H}$, ddd, $J=13.1,3.1,3.1 \mathrm{~Hz}, 4-\mathrm{Heq}), 3.38$ and $3.77-3.83$ (each $\left.1 \mathrm{H}, \mathrm{d}, J=12.4 \mathrm{~Hz}, \mathrm{br}, 6-\mathrm{H}_{2}\right), 3.73(1 \mathrm{H}$, ddd, $J=11.2$, $11.1,3.0 \mathrm{~Hz}, 3-\mathrm{H}), 4.05-5.14(1 \mathrm{H}, \mathrm{m}, 5-\mathrm{H}), 5.09-5.14(1 \mathrm{H}, \mathrm{br}, \mathrm{OH}), 5.18$ $(1 \mathrm{H}, \mathrm{d}, J=11.2 \mathrm{~Hz}, \mathrm{NH}), 7.18\left(1 \mathrm{H}, \mathrm{d}, J=9.4 \mathrm{~Hz}, 6^{\prime}-\mathrm{H}\right.$ in $\left.\mathrm{Ph}-\mathrm{H}\right), 8.15(1 \mathrm{H}$ dd, $J=9.4,2.5 \mathrm{~Hz}, 5^{\prime}-\mathrm{H}$ in $\left.\mathrm{Ph}-\mathrm{H}\right), 8.30\left(1 \mathrm{H}, \mathrm{d}, J=2.5 \mathrm{~Hz}, 3^{\prime}-\mathrm{H}\right.$ in $\left.\mathrm{Ph}-\mathrm{H}\right)$, $12.24-12.95(1 \mathrm{H}, \mathrm{br}, \mathrm{COOH}) .{ }^{13} \mathrm{C}-\mathrm{NMR}\left(\mathrm{DMSO}-d_{6}\right) \delta: 34.0(\mathrm{t}), 60.2(\mathrm{t})$ 61.8 (d), 72.2 (d), 115.1 (d), 121.8 (d), 126.9 (d), 135.4 (s), 136.8 (s), 148.1 (s), 172.7 (s). Anal. Calcd for $\mathrm{C}_{11} \mathrm{H}_{12} \mathrm{~N}_{4} \mathrm{O}_{7}: \mathrm{C}, 42.31 ; \mathrm{H}, 3.87 ; \mathrm{N}, 17.94$ Found: C, 42.63; H, 3.97; N, 17.65

Di-tert-butyl trans-5-Chloro-3-cyanohexahydropyridazine-1,2-dicarboxylate (24) A mixture of $18(0.57 \mathrm{~g}, 1.73 \mathrm{mmol}), \mathrm{CCl}_{4}(2.6 \mathrm{ml})$ and $\mathrm{PPh}_{3}$ $(0.76 \mathrm{~g}, 2.86 \mathrm{mmol})$ in dry THF $(2.6 \mathrm{ml})$ was stirred at $20^{\circ} \mathrm{C}$ under argon atmosphere for $3 \mathrm{~d}$, and then evaporated in vacuo. The residue was treated with a mixed solvent of $\mathrm{AcOEt}, \mathrm{CHCl}_{3}$ and hexane $(5,21,14 \mathrm{ml})$. After filtration off for removal of the precipitate $\left(\mathrm{Ph}_{3} \mathrm{PO}\right)$, the obtained filtrate was concentrated in vacuo. The residue was chromatographed on silica gel using hexane-AcOEt to give 24. Colorless prisms, mp 119-120 ${ }^{\circ} \mathrm{C}$ (from hexane), $70 \%$ yield. MS $m / z$ 345, $347\left(\mathrm{M}^{+}\right)$. IR $(\mathrm{KBr}) \mathrm{cm}^{-1}: 2256(\mathrm{CN})$ $1712(\mathrm{C}=\mathrm{O}) .{ }^{1} \mathrm{H}-\mathrm{NMR}\left(\mathrm{CDCl}_{3}\right) \delta: 1.49,1.50$ and 1.51 (total $18 \mathrm{H}$, each s, intensity ratio $4: 7: 1, t$ - $\mathrm{Bu} \times 2$ ), 2.06 and 2.46 (each $1 \mathrm{H}$, ddd, $J=13.5,12.0$, 
$5.5 \mathrm{~Hz}$ and ddd, $\left.J=13.5,2.1,2.1 \mathrm{~Hz}, 4-\mathrm{H}_{2}\right), 2.74-3.09,4.32-4.44$ and 4.60 (total $2 \mathrm{H}$, intensity ratio $6: 1: 5, \mathrm{~m}, \mathrm{~m}$ and $\mathrm{dd}, J=13.3,3.9 \mathrm{~Hz}, 6-\mathrm{H}_{2}$ ), 4.13 $4.27(1 \mathrm{H}, \mathrm{m}, 5-\mathrm{H}), 5.11-5.30$ and $5.30-5.54$ (total $1 \mathrm{H}$, intensity ratio $3: 7$, each br, 3-H). ${ }^{13} \mathrm{C}-\mathrm{NMR}\left(\mathrm{CDCl}_{3}\right) \delta: 27.9$ (q), $28.1(\mathrm{q}), 36.9$ (t), 44.2 (d), $48.3(\mathrm{t}), 49.8$ (d), 82.8 (s), 83.4 (s), 116.7 (s), 152.3 (s), 152.9 (s). Anal. Calcd for $\mathrm{C}_{15} \mathrm{H}_{24} \mathrm{ClN}_{3} \mathrm{O}_{4}$ : C, 52.10; $\mathrm{H}, 7.00 ; \mathrm{N}, 12.15$. Found: C, 52.27; $\mathrm{H}$, 6.95; N, 12.21.

Di-tert-butyl cis-5-Chloro-3-cyanohexahydropyridazine-1,2-dicarboxylate (25) The title compound was prepared from 19 in a similar manner to that described for 24. Colorless prisms, mp $129-130^{\circ} \mathrm{C}$ (from benzene-hexane), $60 \%$ yield. MS $m / z$ 345, $347\left(\mathrm{M}^{+}\right)$. IR $(\mathrm{KBr}) \mathrm{cm}^{-1}: 2245$ $(\mathrm{CN}), 1728,1705(\mathrm{C}=\mathrm{O}) .{ }^{1} \mathrm{H}-\mathrm{NMR}\left(\mathrm{CDCl}_{3}\right) \delta$ : $1.49,1.53$ and 1.54 (total $18 \mathrm{H}$, intensity ratio $3: 3: 4$, each $\mathrm{s}, t-\mathrm{Bu} \times 2), 2.30-2.34\left(2 \mathrm{H}, \mathrm{m}, 4-\mathrm{H}_{2}\right)$, $3.20-3.54,4.35$ and 4.54 (total $2 \mathrm{H}$, intensity ratio $5: 1: 4, \mathrm{~m}, \mathrm{~d}, J=14.2 \mathrm{~Hz}$ and $\left.\mathrm{dd}, J=14.4,1.8 \mathrm{~Hz}, 6-\mathrm{H}_{2}\right), 4.24-4.32(1 \mathrm{H}, \mathrm{m}, 5-\mathrm{H}), 5.05-5.25$ and $5.25-5.43$ (total $1 \mathrm{H}$, intensity ratio $4: 1$, each br, $3-\mathrm{H}) .{ }^{13} \mathrm{C}-\mathrm{NMR}\left(\mathrm{CDCl}_{3}\right)$ $\delta: 27.9(\mathrm{q}), 28.1$ and 28.2 (each q), 33.6 and 33.8 (each t), $38.7(\mathrm{~d}), 49.3(\mathrm{t})$ 50.7 and 50.9 (each d), 82.5 (s), 83.2 (s), 116.6 (s), 152.5 (s), 152.7 (s). Anal. Calcd for $\mathrm{C}_{15} \mathrm{H}_{24} \mathrm{ClN}_{3} \mathrm{O}_{4}: \mathrm{C}, 52.10 ; \mathrm{H}, 7.00 ; \mathrm{N}, 12.15$. Found: $\mathrm{C}$, 52.04; H, 6.75; N, 12.12 .

trans-5-Chloro-1-(2,4-dinitrophenyl)hexahydropyridazine-3-carboxylic Acid (27) The title compound was prepared from 24 in a similar manner to that described for 22 . Yellow prisms, mp $186-189^{\circ} \mathrm{C}$ (decomp., from EtOH-ether-hexane), 81\% yield. MS $m / z$ 330, $332\left(\mathrm{M}^{+}\right)$. IR (KBr) $\mathrm{cm}^{-1}: 3263(\mathrm{OH}, \mathrm{NH}), 1736,1608(\mathrm{C}=\mathrm{O}) .{ }^{1} \mathrm{H}-\mathrm{NMR}\left(\mathrm{DMSO}-d_{6}\right) \delta: 1.98$ $2.19\left(2 \mathrm{H}, \mathrm{m}, 4-\mathrm{H}_{2}\right), 3.55-3.75,3.95-4.22\left(\right.$ each $1 \mathrm{H}$, br, 6- $\left.\mathrm{H}_{2}\right), 3.80(1 \mathrm{H}$, ddd, $J=11.0,11.0,3.5 \mathrm{~Hz}, 3-\mathrm{H}), 4.84(1 \mathrm{H}, \mathrm{br}, 5-\mathrm{H}), 5.39(1 \mathrm{H}, \mathrm{d}, J=11.1 \mathrm{~Hz}$, $\mathrm{NH}), 7.24\left(1 \mathrm{H}, \mathrm{d}, J=9.5 \mathrm{~Hz}, 6^{\prime}-\mathrm{H}\right.$ in $\left.\mathrm{Ph}-\mathrm{H}\right), 8.19\left(1 \mathrm{H}, \mathrm{dd}, J=9.5,2.7 \mathrm{~Hz}, 5^{\prime}-\right.$ $\mathrm{H}$ in $\mathrm{Ph}-\mathrm{H}), 8.36\left(1 \mathrm{H}, \mathrm{d}, J=2.7 \mathrm{~Hz}, 3^{\prime}-\mathrm{H}\right.$ in $\left.\mathrm{Ph}-\mathrm{H}\right), 12.9(1 \mathrm{H}$, br s, $\mathrm{COOH})$. ${ }^{13}$ C-NMR (DMSO- $d_{6}$ ) $\delta: 34.7(\mathrm{t}), 51.9(\mathrm{t}), 52.4(\mathrm{~d}), 55.0(\mathrm{~d}), 115.1(\mathrm{~d})$, 121.8 (d), 127.2 (d), 136.6 (s), 137.4 (s), 147.5 (s), 171.8 (s). Anal. Calcd for $\mathrm{C}_{11} \mathrm{H}_{11} \mathrm{ClN}_{4} \mathrm{O}_{6}$ : C, 39.95; H, 3.35; N, 16.94. Found: C, 40.07; H, 3.47; N, 16.79 .

Di-(-)-menthyl 3-Cyano-1,2,3,6-tetrahydropyridazine-1,2-dicarboxylate (29) The title compound was prepared as a mixture of the diastereomers from 3 and menthyl carboxylate $(\mathbf{2 8})^{28)}$ in a similar manner to that described for 6. Colorless oil, $99 \%$ yield. MS $m / z 473\left(\mathrm{M}^{+}\right)$. IR (neat) $\mathrm{cm}^{-1}$ : $2245(\mathrm{CN}), 1713(\mathrm{C}=\mathrm{O}) .{ }^{1} \mathrm{H}-\mathrm{NMR}\left(\mathrm{CDCl}_{3}\right) \delta: 0.67-1.15\left(24 \mathrm{H}, \mathrm{m}, 2^{\prime}\right.$-isopropyl-H×2, $\left.5^{\prime}-\mathrm{Me} \times 2,4^{\prime}-\mathrm{H}_{2} \times 2\right), 1.29-1.57\left(4 \mathrm{H}\right.$, br, $\left.3^{\prime}-\mathrm{H}_{2} \times 2\right), 1.62$ $2.21\left(8 \mathrm{H}, \mathrm{m}, 2^{\prime}-\mathrm{H} \times 2,5^{\prime}-\mathrm{H} \times 2,6^{\prime}-\mathrm{H}_{2} \times 2\right), 3.61-4.00$ and $4.35-4.82(1 \mathrm{H}$, $\left.\mathrm{m}, 3 \mathrm{H}, \mathrm{m}, 6-\mathrm{H}_{2} \times 2,1^{\prime}-\mathrm{H} \times 2\right), 5.27-5.73(1 \mathrm{H}, \mathrm{br}, 3-\mathrm{H}), 5.85(1 \mathrm{H}$, br s, $4-\mathrm{H})$, $6.11(1 \mathrm{H}$, br s, $5-\mathrm{H})$.

Hydrogenation of 29 with $\mathbf{7 0} \% \mathbf{H C l O}_{4}$ Compound 29 was hydrogenated in EtOH and worked up as described for $\mathbf{9}$ to give $\mathbf{3 0}$ and $\mathbf{3 1}$.

Di-(-)-menthyl (3R)-3-Cyanohexahydropyridazine-1,2-dicarboxylate (30) Colorless prisms, mp $108-109{ }^{\circ} \mathrm{C}$ (from hexane). MS (FAB) $m / z 476$ $\left(\mathrm{MH}^{+}\right)$. IR $(\mathrm{KBr}) \mathrm{cm}^{-1}: 2251(\mathrm{CN}), 1716(\mathrm{C}=\mathrm{O}) .{ }^{1} \mathrm{H}-\mathrm{NMR}\left(\mathrm{CDCl}_{3}\right) \delta$ : $0.67-1.15\left(24 \mathrm{H}, \mathrm{m}, 2^{\prime}\right.$-isopropyl-H $\left.\times 2,5^{\prime}-\mathrm{Me} \times 2,4^{\prime}-\mathrm{H}_{2} \times 2\right), 1.23-1.56$ $\left(4 \mathrm{H}, \mathrm{m}, 3^{\prime}-\mathrm{H}_{2} \times 2\right), 1.60-2.20\left(12 \mathrm{H}, \mathrm{m}, 2^{\prime}-\mathrm{H} \times 2,5^{\prime}-\mathrm{H} \times 2,6^{\prime}-\mathrm{H}_{2} \times 2,4-\mathrm{H}_{2}\right.$, $\left.5-\mathrm{H}_{2}\right),[2.73-3.08(1 \mathrm{H}, \mathrm{m}), 4.19$ and 4.34 (total $1 \mathrm{H}$, intensity ratio $1: 4$, each $\mathrm{d}, J=13.5$ and $\left.11.7 \mathrm{~Hz}), 6-\mathrm{H}_{2}\right], 4.50-4.76\left(2 \mathrm{H}, \mathrm{m}, 1^{\prime}-\mathrm{H} \times 2\right), 5.13$ $5.48\left(1 \mathrm{H}\right.$, br, 3-H). $[\alpha]_{\mathrm{D}}^{25}-26.8\left(c=0.95, \mathrm{CHCl}_{3}\right)$. Anal. Calcd for $\mathrm{C}_{27} \mathrm{H}_{45} \mathrm{~N}_{3} \mathrm{O}_{4}: \mathrm{C}, 68.18 ; \mathrm{H}, 9.54 ; \mathrm{N}, 8.83$. Found: $\mathrm{C}, 68.12 ; \mathrm{H}, 9.34 ; \mathrm{N}, 8.81$.

Di-(-)-menthyl (3S)-3-Cyanohexahydropyridazine-1,2-dicarboxylate (31) Colorless prisms, mp $50-51^{\circ} \mathrm{C}$ (from hexane). MS (FAB) $m / z 476$ $\left(\mathrm{MH}^{+}\right)$. IR ( KBr) cm ${ }^{-1}: 2249(\mathrm{CN}), 1732,1709(\mathrm{C}=\mathrm{O}) .{ }^{1} \mathrm{H}-\mathrm{NMR}\left(\mathrm{CDCl}_{3}\right)$ $\delta$ : $0.70-1.15\left(24 \mathrm{H}, \mathrm{m}, 2^{\prime}\right.$-isopropyl-H×2, $\left.5^{\prime}-\mathrm{Me} \times 2,4^{\prime}-\mathrm{H}_{2} \times 2\right), 1.30-1.57$ $\left(4 \mathrm{H}, \mathrm{m}, 3^{\prime}-\mathrm{H}_{2} \times 2\right), 1.62-2.19\left(12 \mathrm{H}, \mathrm{m}, 2^{\prime}-\mathrm{H} \times 2,5^{\prime}-\mathrm{H} \times 2,6^{\prime}-\mathrm{H}_{2} \times 2,4-\mathrm{H}_{2}\right.$, $\left.5-\mathrm{H}_{2}\right),[2.75-3.18(1 \mathrm{H}, \mathrm{m}), 4.17$ and 4.33 (total $1 \mathrm{H}$, intensity ratio $2: 3$, each $\mathrm{d}, J=12.8$ and $\left.11.5 \mathrm{~Hz}), 6-\mathrm{H}_{2}\right], 4.50-4.77\left(2 \mathrm{H}, \mathrm{m}, 1^{\prime}-\mathrm{H} \times 2\right), 5.12$ $5.44\left(1 \mathrm{H}\right.$, br, 3-H). $[\alpha]_{\mathrm{D}}^{25}-82.9\left(c=0.97, \mathrm{CHCl}_{3}\right)$. Anal. Calcd for $\mathrm{C}_{27} \mathrm{H}_{45} \mathrm{~N}_{3} \mathrm{O}_{4}: \mathrm{C}, 68.18 ; \mathrm{H}, 9.54 ; \mathrm{N}, 8.83$. Found: C, 67.99; H, 9.23; N, 8.67.

(3R)-Hexahydropyridazine-3-carboxylic Acid Trifluoroacetic Acid (32) The title compound was prepared from $\mathbf{3 0}$ in a similar manner to that described for 13. White powder, mp $145-147^{\circ} \mathrm{C}$ (from EtOH-AcOEt) (lit. $\left.{ }^{14)} \mathrm{mp} 147-149^{\circ} \mathrm{C}\right), 95 \%$ yield. IR $(\mathrm{KBr}) \mathrm{cm}^{-1}: 3442,3292,3080(\mathrm{OH}$, $\mathrm{NH}), 1720,1664(\mathrm{C}=\mathrm{O}) .[\alpha]_{\mathrm{D}}^{22}-11.6(c=0.97, \mathrm{MeOH})$.

(3S)-Hexahydropyridazine-3-carboxylic Acid Trifluoroacetic Acid (33) The title compound was prepared from $\mathbf{3 1}$ in a similar manner to that described for 13. White powder, mp $145-147^{\circ} \mathrm{C}$ (from EtOH-AcOEt) (lit. $\left.{ }^{16)} \mathrm{mp} 149-151^{\circ} \mathrm{C}\right), 91 \%$. IR (KBr) cm ${ }^{-1}: 3442,3292,3080(\mathrm{OH}, \mathrm{NH})$, $1720,1664(\mathrm{C}=\mathrm{O}) .[\alpha]_{\mathrm{D}}^{28}+11.6(c=1.03, \mathrm{MeOH})$.

Acknowledgements This work was partially supported by The Specific Research Fund of Hokuriku University.

\section{References}

1) Maehr H., Liu C.-M., Palleroni N. J., Smallheer J., Todaro L., Williams T. H., Blount J. F., J. Antibiot., 39, 17-25 (1986).

2) Sugawara K., Toda S., Moriyama T., Konishi M., Oki T., J. Antibiot., 46, 928-935 (1993).

3) Grafe U., Schlegel R., Ritzau M., Ihn W., Dornberger K., Stengel C., Fleck W. F., Gutshe W., Hartle A., J. Antibiot., 48, 119-125 (1995).

4) Hensens O. D., Borris R. P., Koupal L. R., Caldwell C. G., Currie S. A., Haidri A. A., Homnick C. F., Honeycutt S. S., Lindenmayer S. M., Schwartz C. D., Weissberger B. A., Woodruff H. B., Zink D. L., Zitano L., Fieldhouse J. M., Rollins T., Springer M. S., Springer J. P., J. Antibiot., 44, 249-254 (1991).

5) Ueno M., Amemiya M., Someno T., Masuda T., Iinuma H., Naganawa H., Hamada M., Ishizuka M., Takeuchi T., J. Antibiot., 46, 1658 1665 (1993).

6) Pettibone D. J., Clineschmidt B. V., Anderson P. S., Freidinger R. M., Lundell G. F., Koupal L. R., Schwartz C. D., Williamson J. M., Goetz M. A., Hensens O. D., Liesch J. M., Springer J. P., Endocrinology, 125, 217-222 (1989).

7) Ogita T., Sato A., Enokita R., Suzuki K., Ishii M., Negishi T., Okazaki T., Tamaki K., Tanzawa K., J. Antibiot., 45, 1723-1732 (1992).

8) Tamaki K., Ogita T., Tanzawa K., Sugimura Y., Tetrahedron Lett., 34, 683 - 686 (1993)

9) Tamaki K., Kurihara S., Sugimura Y., Tetrahedron Lett., 34, 84778480 (1993).

10) Hassall C. H., Bevan K., Davies J. S., Morton R. B., Phillips D. A. S., J. Chem. Soc. (C), 1971, 514-522 (1971).

11) Briden W., O’Murchu C., PCT Int. Appl. 14 pp. WO 20011056997 (2001) [Chem. Abstr., 135, 137513 (2001)].

12) Hassall C. H., Ramachandran K. L., Heterocycles, 7, 119-122 (1977).

13) Davis C. R., Davis J. S., J. Chem. Soc. Perkin Trans. 1, 1979, 2390 2394 (1979).

14) Hale K. J., Cai J., Delisser V., Manaviazar S., Peak S. A., Bhatia G. S., Collins T. C., Jogiya N., Tetrahedron, 52, 1047-1068 (1996).

15) Hale K. J., Jogiya N., Manaviazar S., Tetrahedron Lett., 39, 71637166 (1998).

16) Henmi Y., Makino K., Yoshitomi Y., Hara O., Hamada Y., Tetrahedron Asymmetry, 15, 3477-3481 (2004).

17) Makino K., Henmi Y., Terasawa M., Hara O., Hamada Y., Tetrahedron Lett., 46, 555-558 (2005).

18) Kaname M., Yoshinaga K., Arakawa Y., Yoshifuji S., Chem. Pharm. Bull., 52, 160-162 (2004).

19) Kaname M., Yoshinaga K., Arakawa Y., Yoshifuji S., Tetrahedron Lett., 40, 7993-7994 (1999).

20) Kaname M., Arakawa Y., Yoshifuji S., Tetrahedron Lett., 42, 2713 2716 (2001).

21) Hassall C. H., Ogihara Y., Thomas W. A., J. Chem. Soc. C, 1971, 522-526 (1971).

22) Mitsunobu O., Synthesis, 1981, 1-27 (1981).

23) Schmidt U., Braun C., Sutoris H., Synthesis, 1996, 223 -229 (1996).

24) Kamenecka T. M., Danishefsky S. J., Angew. Chem. Int. Ed., 37, 2995-2998 (1998).

25) Adlerová E., Bláha L., Borovička M., Emest I., Jilek J. O., Kakáč B., Novák L., Rajšner M., Protiva M., Collect. Czech. Chem. Commun., 25, 221-236 (1960) [Chem. Abstr., 54, 6719i (1960)].

26) Kataoka T., Nito T., Takabe K., Tanaka J., Nippon Kagaku Kaishi, 12, 2370-2374 (1974) [Chem. Abstr., 82, 155249 (1997)].

27) Starr J. T., Rai G. S., Dang S. R., Dang H., Mcnelis B. J., Synth. Commun., 27, 3197-3200 (1997).

28) Brimble M. A., Heathcock C. H., Nobin G. N., Tetrahedron Asymmetry, 7, 2007-2016 (1996). 